Z. Klin. Chem. Klin. Biochem.

13. Jg. 1975, S. 311-318

\title{
The Diagnostic Significance of Liver Cell Inhomogeneity: Serum Enzymes in Patients with Central Liver Necrosis and the Distribution of Glutamate Dehydro- genase in Normal Human Liver
}

\author{
By W. G. Guder, A. Habicht, J. Kleißl ${ }^{1}$ ), U. Schmidt and O. H. Wieland
}

Klinisch-Chemisches Institut, Städt. Krankenhaus München-Schwabing and Cytobiologisches Laboratorium des Pathologischen Instituts der Universität Tübingen

Dedicated to Prof. Dr. mult. E. Letterer on occasion of his 80 th birthday

(Eingegangen am 14. März 1975)

Summary: 16 Patients with acute right-sided cardiac failure associated with a high pressure of the central venous system, exhibited a marked increase in glutamate dehydrogenase activity in serum. This increase was 40 -fold higher than in patients with acute viral hepatitis. Histological examination of seven deceased patients revealed central necrosis within the liver lobule. This observation led us to determine glutamate dehydrogenase activity in microdissected peripheral and central portions from the unchanged liver lobule. A 1.7-fold higher glutamate dehydrogenase activity was found in the central part of the liver lobule than in the peripheral portion. The diagnostic significance of the glutamate dehydrogenase activity distribution along the cords of liver cells is discussed in view of liver diseases with central necrosis.

\section{Zur diagnostischen Bedeutung der Leberzellheterogenität: \\ Serumenzymaktivitäten bei zentraler Lebernekrose und die Verteilung der Glutamatdehydrogenase in normaler menschlicher Leber}

Zusammenfassung: Bei 16 Patienten mit akutem Rechtsherzversagen und plötzlichem Anstieg des zentralvenösen Drucks wurden im Serum ungewöhnlich hohe Aktivitäten der Glutamatdehydrogenase beobachtet. Ein Vergleich mit einem Kollektiv, das an akuter Virushepatitis erkrankt war, ergab bei ähnlichen Erhöhungen der Transaminasen eine 40-fach höhere Glutamatdehydrogenase. 7 Fälle, die verstarben, zeigten histologisch zentrale Nekrosen der Leber. Diese Beobachtung gab den Anlaß zur Bestimmung der Glutamatdehydrogenaseaktivität in mikrodisseziertem Gewebe normaler menschlicher Leber. Dabei wurde eine ungleichmäßige Verteilung der Glutamatdehydrogenase gefunden mit einer etwa 1,7 mal höheren Aktivität in Läppchenzentrum im Vergleich zu periportalen Feldern, bezogen auf Trockengewicht. Die diagnostische Bedeutung der Leberzellheterogenität bei Lebererkrankungen mit zentralen Nekrosen wird diskutiert.

\section{Introduction}

Since the early work of $L a$ Due et al. (1) and de Ritis et al. (2), aminotransferase ${ }^{2}$ ) activities in serum have been extensively used as an indicator of liver cell damage.

1) This work is part of the doctoral thesis of $J$. Kleißl.

$\left.{ }^{2}\right)$ Enzymes: Glutamate dehydrogenase EC 1.4.1.3 Aspartate aminotransferase EC 2.6.1.1 Alanine aminotransferase EC 2.6.1.2 Alkaline Phosphatase EC 3.1.3.1 Creatine kinase EC 2.7.3.2 Lactate dehydrogenase EC 1.1.1.27 Cholinesterase EC 3.1.1.8 $\gamma$-glutamyltransferase EC 2.3.2.1
Based on their clinical and experimental work, Schmidt $\& \operatorname{Schmidt}(3,4)$ reported that the glutamate dehydrogenase in serum could be of additional diagnostic aid in differentiating various forms of liver disease. The distribution pattern of alanine aminotransferase, aspartate aminotransferase and glutamate dehydrogenase within the liver cells $(5,6)$ brought these authors to the suggestion that the various enzyme activity ratios pointed out by de Ritis et al. (2) could be caused by the degree of cell damage. This fruitful idea was substantiated by the finding that glutamate dehydrogenase, an exclusively mitochondrial enzyme (6), was found to be increased in serum only under conditions with total cell necrosis 
$(4,5,7)$. Thus low alanine aminotransferase: glutamate dehydrogenase ratios were found in toxic or cholestatic liver damage, necrotizing hepatitis and metastatic liver diseases $(4,7)$.

During the past years, serum enzyme changes after acute right-sided cardiac failure with central liver necrosis have been reported (7-10). An essential feature was a relatively high serum glutamate dehydrogenase activity exceeding that found in acute viral hepatitis. This observation brought us to suggest that intralobular site of liver cell necrosis could be an additional reason for the various serum enzyme patterns found in different liver diseases.

Determination of alanine aminotransferase and glutamate dehydrogenase in rat liver with the methods of quantitative histochemistry revealed a characteristic distribution pattern of both enzymes along the cords of liver cells $(11,12)$. In accordance with our hypothesis, alanine aminotransferase was found to be higher in the peripheral part of the liver lobule, whereas glutamate dehydrogenase exhibited an inverse distribution (12).

The present report deals with studies on 16 patients with acute right-sided cardiac failure associated with liver enlargement due to venous congestion. These patients exhibited relatively higher serum glutamate dehydrogenase activities than usually observed in other liver diseases. In addition, the distribution of glutamate dehydrogenase in microdissected tissue samples from human liver lobules was evaluated. Our results have been partially published in a preliminary form $(13,14)$.

\section{Materials and Methods.}

\section{Biopsy}

Liver specimens were obtained from the margin of the right lobule of patients during operation for gall bladder and stomach diseases (tab. 2). The integrity of liver tissue was controlled by histological examination and by analyzing the serum enzyme pattern from these patients.

\section{Preparation}

The procedure of tissue preparation for microdissection, the isolation of single areas from the liver lobule, and the analysis of glutamate dehydrogenase on the microchemical scale was performed according to the method developed originally by Lowry et al. (15) and adapted for renal tissue $(16,17)$. Liver tissue was sliced into small specimens $(3 \times 3 \times 5 \mathrm{~mm})$, mounted on a tissuc holder with Tragacanth (Merck) and plunged into liquid nitrogen. The freezing procedure was done as quickly as possible $(60 \mathrm{~s})$. The loaded holder was transferred into a cryostat, equipped with a microtome, and the liver tissue was cut serially after equilibration of the tissue temperature, which takes about one hour. We prefer sections $16 \mu \mathrm{m}$ in thickness. The first and third of three consecutive sections were transferred to a special holder which consisted of a drilled plastic block between glass slides. The filled holder was transferred into a tube for vacuum drying the sections at 0.01 Torr for at least 12 hours at $-40^{\circ} \mathrm{C}$. The second section was stained with periodic acid Schiffs base reagent and served to identify the peripheral and central areas of the liver lobule within the lyophilized sections.

\section{$\cdot$}

\section{Microdissection}

Rewarming of the tubes was done at room temperature under vacuum. The tube was then brought into a room with controlled temperature and humidity $\left(20^{\circ} \mathrm{C}\right.$ and $40 \%$ relative humidity), opened and the tissue taken out for dissection. Tissue dissection, weighing on a self-made quartz-fiber balance $(15,16)$, and the loading of microtest tubes with the samples of 10 to 40 nanogram dry weight were carried out in the same room.

\section{Analysis of glutamate dehydrogenase}

Glutamate dehydrogenase activity was determined by a modification of the method described by Lowry et al. (18) in which the fluorescence of $\mathrm{NAD}^{+}$formed upon incubation of 10-40 ng freeze-dried liver tissue is measured. The tissue was incubated in $5 \mu \mathrm{l}$ of $63 \mathrm{mmol} / \mathrm{l}$ triethanolamine hydrochloride buffer, $\mathrm{pH} 8$, containing $5 \mathrm{mmol} / \mathrm{l} 2$-oxoglutarate, $1 \mathrm{mmol} / \mathrm{l} \mathrm{NADH}$, $2 \mathrm{mmol} / \mathrm{l} \mathrm{ADP}, 200 \mathrm{mmol} / \mathrm{l}$ ammonium acetate, $1 \mathrm{mmol} / \mathrm{l}$ EDTA and $0.5 \mathrm{~g} / \mathrm{l}$ bovine serum albumin. The incubation mixture was found to be optimal for analyzing glutamate dehydrogenase activity in lyophilized human liver homogenate (fig. 1).

The samples were incubated at $25^{\circ} \mathrm{C}$ for $30 \mathrm{~min}$. After they were transferred to an ice bath, $1 \mu \mathrm{l}$ of $1 \mathrm{~mol} / 1 \mathrm{HCl}$ was added to stop the reaction and to destroy excess NADH. After $10 \mathrm{~min}$ at room temperature, $2 \mu \mathrm{l}$ of each sample was added to $200 \mu \mathrm{l}$ of $6,6 \mathrm{~mol} / 1 \mathrm{NaOH}$ and incubated at $60^{\circ} \mathrm{C}$ for $10 \mathrm{~min}(18)$, whereby $\mathrm{NAD}^{+}$is converted to a highly fluorescent state. The fluorescence was measured with a Farrand spectral fluorometer using $340 \mathrm{~nm}$ as the primary and $462 \mathrm{~nm}$ as the secondary wavelength. The standards contained $50,100,200 \mu \mathrm{mol} / 1 \mathrm{NAD}{ }^{+}$

Linear $\mathrm{NAD}^{+}$production was obtained with single microdissected portions from 5 to $130 \mathrm{ng}$ dry weight. Controls of liver tissue incubated in the absence of 2-oxoglutarate revealed no fluorescence. Enzyme activity is expressed as $\mu \mathrm{mol} / \mathrm{min}(=\mathrm{U})$ $\mathrm{NAD}^{+}$formed per $\mathrm{g}$ dry weight.

\section{Clinical studies}

Central venous blood pressure was measured with plastic catheters of $1 \mathrm{~mm}$ width (Braun, Melsungen, Germany) in the upper caval vein. Enzyme determinations in serum were performed with standard methods (19-21) using a fully automated Eppendorf 5010 apparatus. All determinations were done on the day of blood withdrawal using reagents from Boehringer, Mannheim, Germany and E. Merck, Darmstadt, Germany. Normal values were from $(20-22)$ and are given in the legends to table 1.

\section{Statistical evaluation of results}

Since normal distribution could not always be ascertained, results were analyzed on probality nets, and medians \pm 25 percentiles were determined graphically (23). Statistical significance was determined with the Students t-test and the rank test of Wilcoxon, Mann \& Whitney (23). 


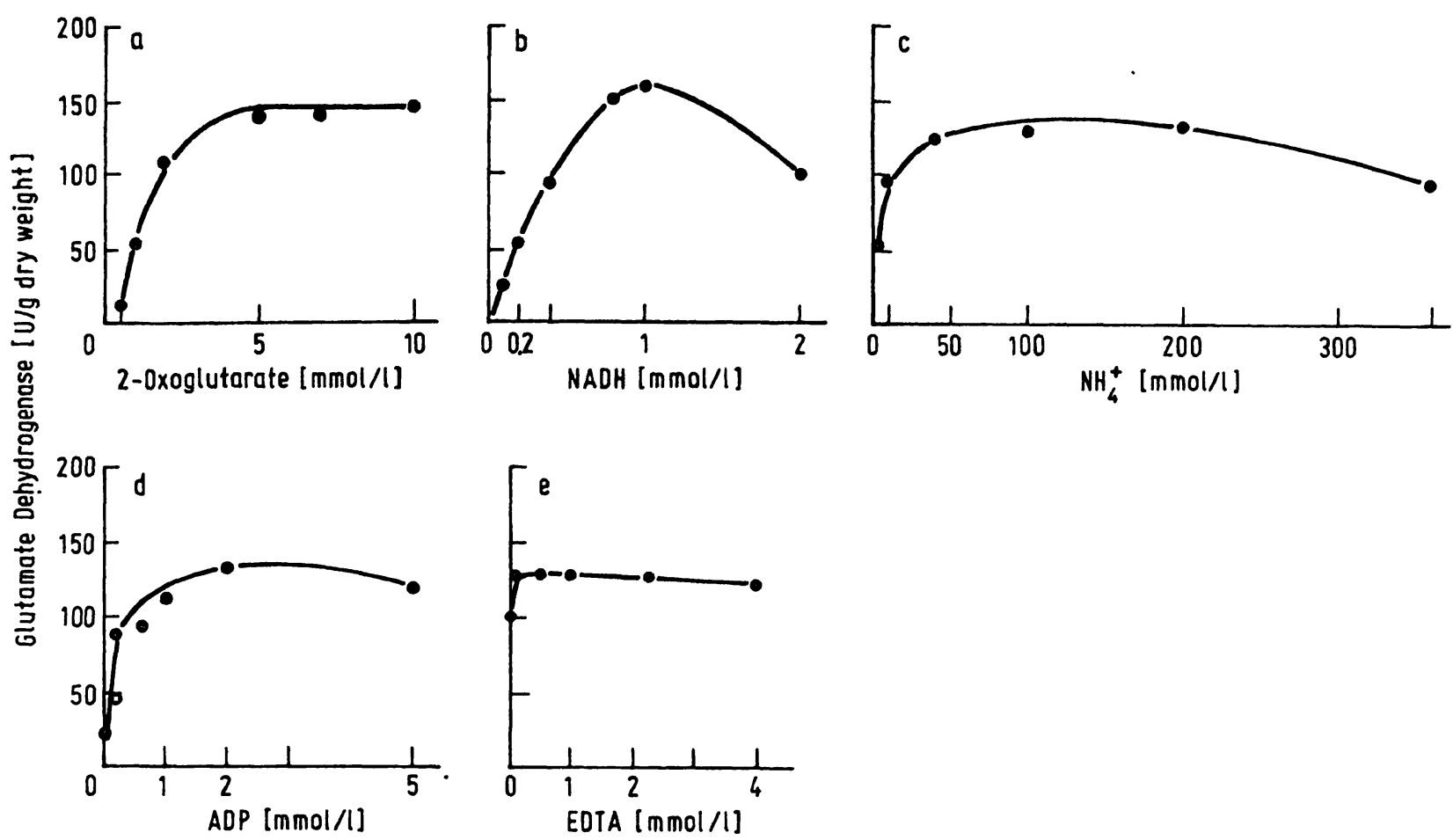

Fig. 1. Optimal conditions for the determination of glutamate dehydrogenase activity in lyophilized human liver samples.

The human liver specimen was taken during laparatomy, sliced and frozen in liquid nitrogen as described in the methods. A piece of $368 \mathrm{mg}$ wet weight was homogenized in distilled water with an Ultra Turrax $10 \mathrm{~N}$ (Janke \& Kunkel, Stauffen, Germany) to result in a final wet weight tissue concentration of $37 \mathrm{mg} / \mathrm{ml}$. The homogenate was lyophilized in aliquots of $200 \mu \mathrm{l}$ at $-40^{\circ} \mathrm{C}$ and 0.01 Torr over 16 hours. The freeze-dried tissue was taken up in distilled water and further diluted with incubation mixture to a final dry weight tissue concentration of $10 \mu \mathrm{g} / \mathrm{ml}$. Glutamate dehydrogenase activity was then determined as described in the methods section with the concentrations found to be optimal for the assay in human serum (19). The concentrations of the components were then varied, and the optimum found for each component was then used for the next assay, resulting in the following final concentrations:

\begin{tabular}{|c|c|c|c|c|c|c|}
\hline Experiment (cf. figure) & $\mathbf{a}$ & b & c & d & e & final assay \\
\hline Triethanolamine $\mathrm{HCl} \mathrm{pH} 8.0(\mathrm{mmol} / \mathrm{l})$ & 63 & 63 & 63 & 63 & 63 & 63 \\
\hline 2-oxoglutarate $(\mathrm{mmol} / \mathrm{l})$ & var. & 5 & 5 & 5 & 5 & 5 \\
\hline $\mathrm{NADH}(\mathrm{mmol} / \mathrm{l})$ & 1 & var. & 1 & 1 & 1 & 1 \\
\hline $\mathrm{NH}_{4}^{+}(\mathrm{mmol} / \mathrm{l})$ & 100 & 100 & var. & 200 & 200 & 200 \\
\hline $\mathrm{ADP}(\mathrm{mmol} / \mathrm{l})$ & 1 & 1 & 1 & var. & 2 & 2 \\
\hline $\operatorname{EDTA}(\mathrm{mmol} / \mathrm{l})$ & 2.5 & $2 . \overline{5}$ & 2.5 & 2.5 & var. & 1 \\
\hline bovine serum albumin $(\mathrm{g} / \mathrm{l})$ & 0.5 & 0.5 & 0.5 & 0.5 & 0.5 & $0 . \overline{5}$ \\
\hline
\end{tabular}

\section{Results and Discussion}

Serum enzyme pattern in patients with acute right heart failure

The observation of extremely high activities of glutamate dehydrogenase (above $1000 \mathrm{U} / \mathrm{l}$ ) in serum of patients in the intensive care unit stimulated us to look for an explanation for this unusual enzyme pattern. It turned out that the central venous pressure had acutely increased in all patients due to myocardial infarction, pulmonary embolism or other diseases complicated by acute right-sided cardiac failure. A typical patient is documented in figure 2, which stands for all other patients summarized in table 1.

Liver enlargement was found in almost all cases. Half of the patients died a few days later, and in these cases, various degrees of central liver necrosis were histologically confirmed. None of the patients exhibited : decrease in systolic blood pressure below $90 \mathrm{~mm} \mathrm{Hg}$.
Alanine aminotransferase and aspartate aminotransferase activities were found to be increased 5 to 200 fold over the normal upper limits. Although the elevated alanine aminotransferase indicated liver cell damage, the relation of the two aminotransferases (de Ritis ratio) did not allow further diagnostic conclusions because simultaneous increases in heart or/and muscle enzymes (as could be derived from creatine kinase values) complicated the picture. However, the unusually high increase in glutamate dehydrogenase activity in serum, which reached values above 1000 units/l in more than half of the cases seemed in striking contrast to other forms of liver injury. Since glutamate dehydrogenase activity is known to be highest in liver (5), the increase in serum could be interpreted as an indication of acute liver necrosis. As observed earlier by Schmidt \& Schmidt (7), glutamate dehydrogenase activity rapidly returned to normal in parallel to the decrease in central venous blood pressure (fig. 2). This 
Tab. 1. Clinical, chemical and morphological data from 16 patients wich acute right-sided cardiac failure.

All patients were admitted to the internal departments of the Schwabing city hospital and treatcd on the intensive care units.

a) Clinical and morphological data

Arterial and central ?ennus blood pressure, which was measured with a plastic catheter of $1 \mathrm{~mm}$ inner diameter (normal upper limit $=10 \mathrm{~cm} \mathrm{H}_{2} \mathrm{O}$ ) in the uppii caval vein, was taken from the day before enzymes were determined.

Liver enlargement was estimated by palpation and is given according to the following scheme:

$+\quad$ inferior margin of the liver slightly (less than $5 \mathrm{~cm}$ ) broadened

$++\quad$ inferior margin of the liver more than $5 \mathrm{~cm}$ broadened

+++ inferior margin of the liver more than $10 \mathrm{~cm}$ broadened

n.d. $=$ not determined

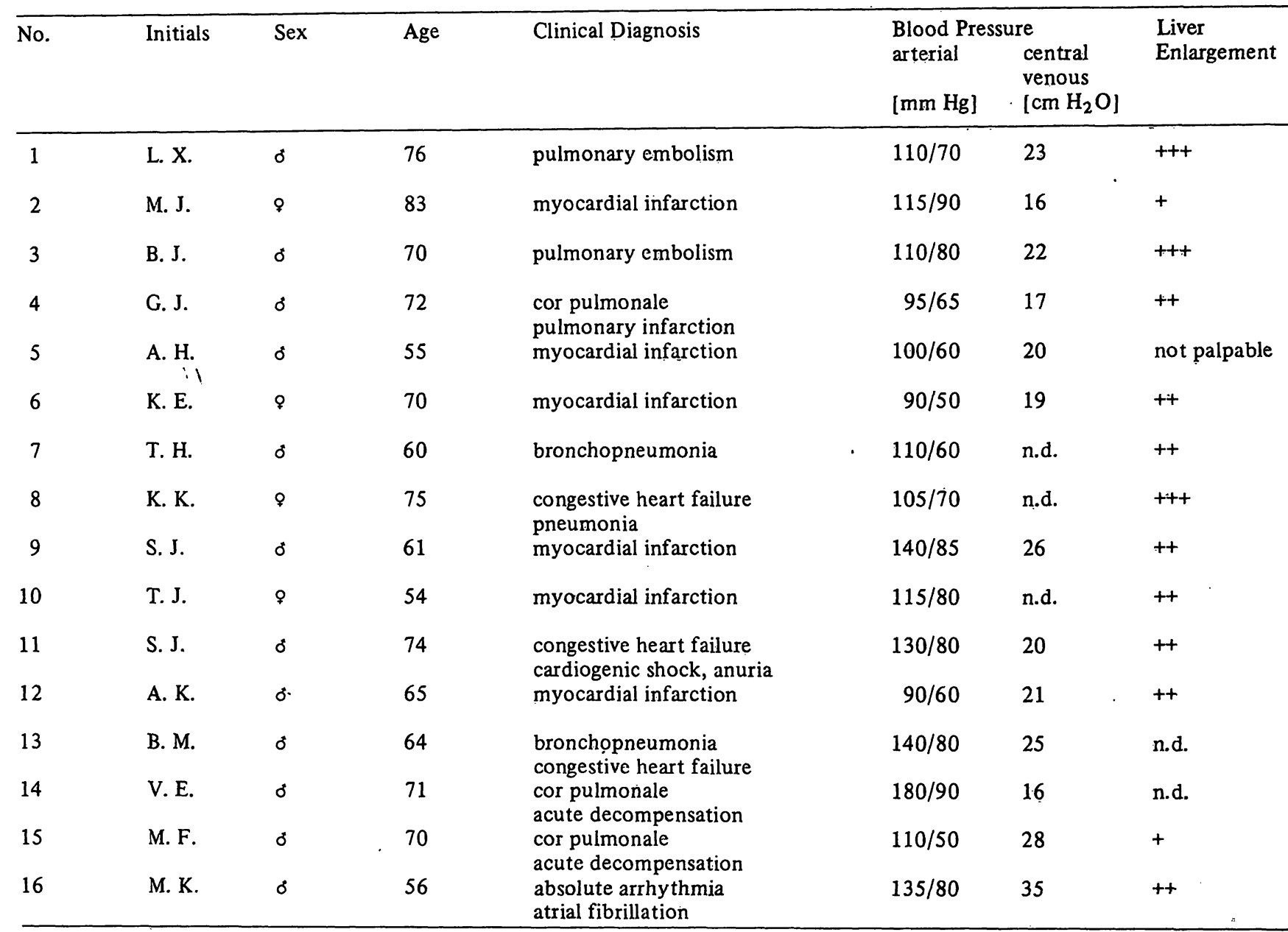

Tab. 1b) Histological findings

Liver histology was obtained at autopsy at the Institute of Pathology of the Schwabing city hospital.

Numbering of patients corresponds to table $1 \mathrm{a}$.

\begin{aligned} & \hline No. Histological findings \\ & \hline 2 diffusc fatty liver, congestive central liver necrosis \\ & 5 heavy central and intermediate necrosis after subacute liver congestion in otherwise normal liver structures. \\ & 8 acute pericentral liver necrosis in chronic congestive cirrhosis of the liver \\ & 9 heavy acute liver congestion with extensive central necrosis \\ & 14 apparently normal liver tissue with signs of acute congestion \\ & 15 chronic congestive liver fibrosis with acute central liver necrosis and fatty degeneration \\ & 16 chronic congestive liver tissue with centroacinar necrosis \\ & \hline\end{aligned}


Tab. 1c) Laboratory findings

The laboratory data were obtained with standard procedures (19-21) from blood withdrawn 1-3 days after the onset of acute right-sided cardiac failure. Normal upper limits are taken from l.c. $(20-22)$.

Numbering of patients corresponds to table $1 \mathrm{a}$.

\begin{tabular}{|c|c|c|c|c|c|c|c|c|c|}
\hline No. & $\begin{array}{l}\text { Aspartate } \\
\text { aminotrans- } \\
\text { ferase } \\
{[U / 1]}\end{array}$ & $\begin{array}{l}\text { Alanine } \\
\text { aminotrans- } \\
\text { fcrase } \\
{[\mathrm{U} / \mathrm{l}]}\end{array}$ & $\begin{array}{l}\text { Glutamate } \\
\text { dehydro- } \\
\text { genase } \\
|U / 1|\end{array}$ & $\begin{array}{l}\text { Lactate } \\
\text { dehydro- } \\
\text { genasc } \\
|U /| \mid\end{array}$ & $\begin{array}{l}\begin{array}{l}\text { Creatine } \\
\text { kinase }\end{array} \\
{[\mathrm{U} / 1]}\end{array}$ & $\begin{array}{l}\text { Alkaline } \\
\text { phospha- } \\
\text { tase } \\
{[U / 1]}\end{array}$ & $\begin{array}{l}\begin{array}{l}\gamma \text {-Glutamyl- } \\
\text { transferase }\end{array} \\
{[\mathrm{U} / 1]}\end{array}$ & $\begin{array}{l}\text { Choline- } \\
\text { esterase }\end{array}$ & [mg/1] \\
\hline $\begin{array}{r}1 \\
2 \\
3 \\
4 \\
5 \\
6 \\
7 \\
8 \\
9 \\
10 \\
11 \\
12 \\
13 \\
14 \\
15 \\
16\end{array}$ & $\begin{array}{r}1950 \\
224 \\
1220 \\
86 \\
340 \\
5250 \\
550 \\
83 \\
2125 \\
625 \\
780 \\
625 \\
580 \\
100 \\
750 \\
350\end{array}$ & $\begin{array}{r}1450 \\
400 \\
875 \\
100 \\
750 \\
3150 \\
410 \\
255 \\
3040 \\
2050 \\
1260 \\
875 \\
455 \\
136 \\
1480 \\
190\end{array}$ & $\begin{array}{r}3000 \\
400 \\
1760 \\
180 \\
1040 \\
1400 \\
1500 \\
175 \\
9000 \\
1500 \\
1600 \\
2900 \\
200 \\
140 \\
760 \\
147\end{array}$ & $\begin{array}{r}1700 \\
232 \\
4900 \\
420 \\
900 \\
11700 \\
1040 \\
\\
4200 \\
1050 \\
\\
1900 \\
1500\end{array}$ & $\begin{array}{r}38 \\
53 \\
1400 \\
404 \\
\\
241 \\
472 \\
30 \\
23 \\
15\end{array}$ & $\begin{array}{r}219 \\
99 \\
89 \\
310 \\
242 \\
132 \\
389 \\
171 \\
\\
132\end{array}$ & $\begin{array}{r}141 \\
52\end{array}$ & $\begin{array}{l}3020 \\
2600\end{array}$ & $\begin{array}{r}<10 \\
<10 \\
<10 \\
13\end{array}$ \\
\hline $\begin{array}{l}\text { normal } \\
\text { upper } \\
\text { limit }\end{array}$ & 17 & 23 & 4 & 240 & 50 & 190 & 28 & $\left.3000^{*}\right)$ & 12 \\
\hline
\end{tabular}

*) lower limit

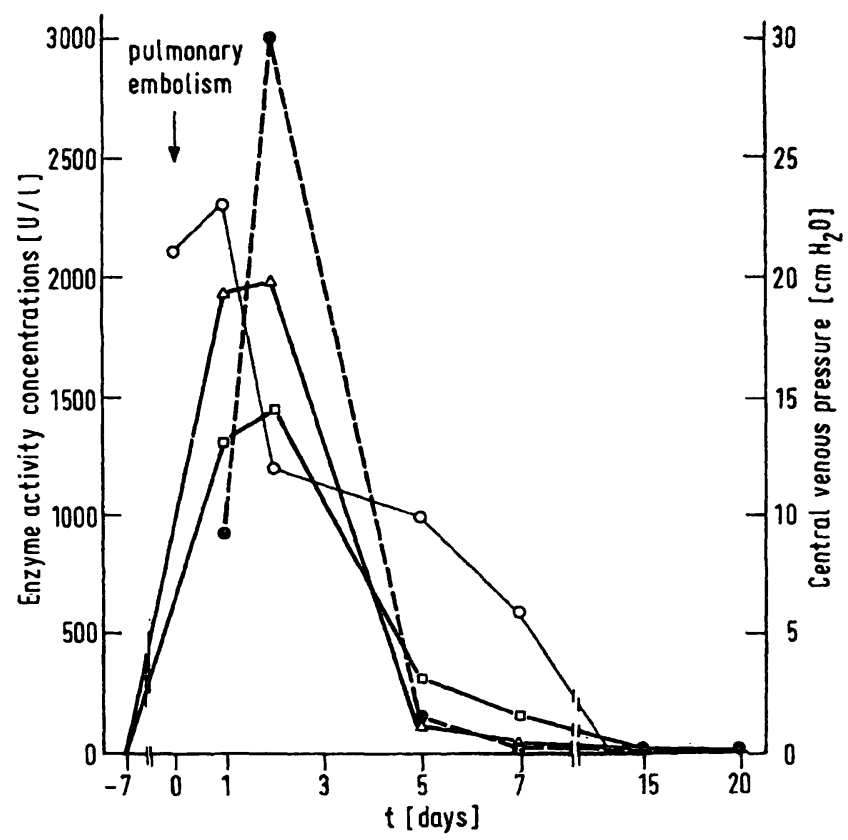

Fig. 2. Serum enzyme activities and central venous pressure after pulmonary embolism with acute right-sided cardiac failure.

The patient L.X. (no. 1 in Table 1), who suffered from cardiac arhythmia, had normal aminotransferase activities on admission to the hospital seven days before the acute attack. Enzyme activities were determined with standard methods (19), central venous pressure was measured in the upper caval vein with a plastic catheter of $1 \mathrm{~mm}$ inner diameter.

$\triangle-\Delta$ aspartate aminotransferase

$\square-\square$ alanine aminotransferasc

- - - glutamate dehydrogenase

- o central venous pressure (right scale). is consistent with a relatively short half-life of glutamate dehydrogenase in serum (24). Alkaline phosphatase was normal in most of our patients. This observation, together with the absence of jaundice (tab. 1) and of histological findings, indicated that cholestasis was not involved in these patients with central liver necrosis.

When the serum enzyme pattern of the patients summarized in table 1 was compared with that of patients suffering from acute viral hepatitis, the results given in figure 3 were obtained.

Whereas aminotransferase activities were not significantly different between the two groups, the stri'cing difference in glutamate dehydrogenase activities in serum was obvious (fig. 3). The ratio of alanine aminotransferase: glutamate dehydrogenase differed by a factor of 40 , ranging from 0.25 to 2.2 in the cases with acute right heart failure, and from 15 to 138 in those with hepatitis.

It is well known that viral hepatitis is characterized not only by a less severe liver cell damage, but also by a more diffuse distribution of damaged cells (25). From this we suggested that not only the degree of cell damage, but likewise the intralobular site of necrosis might be responsible for the difference in the enzyme pattern between the two groups. Our studies on the localization of glutamate dehydrogenase activities in normal human liver seem to be consistent with this explanation. 

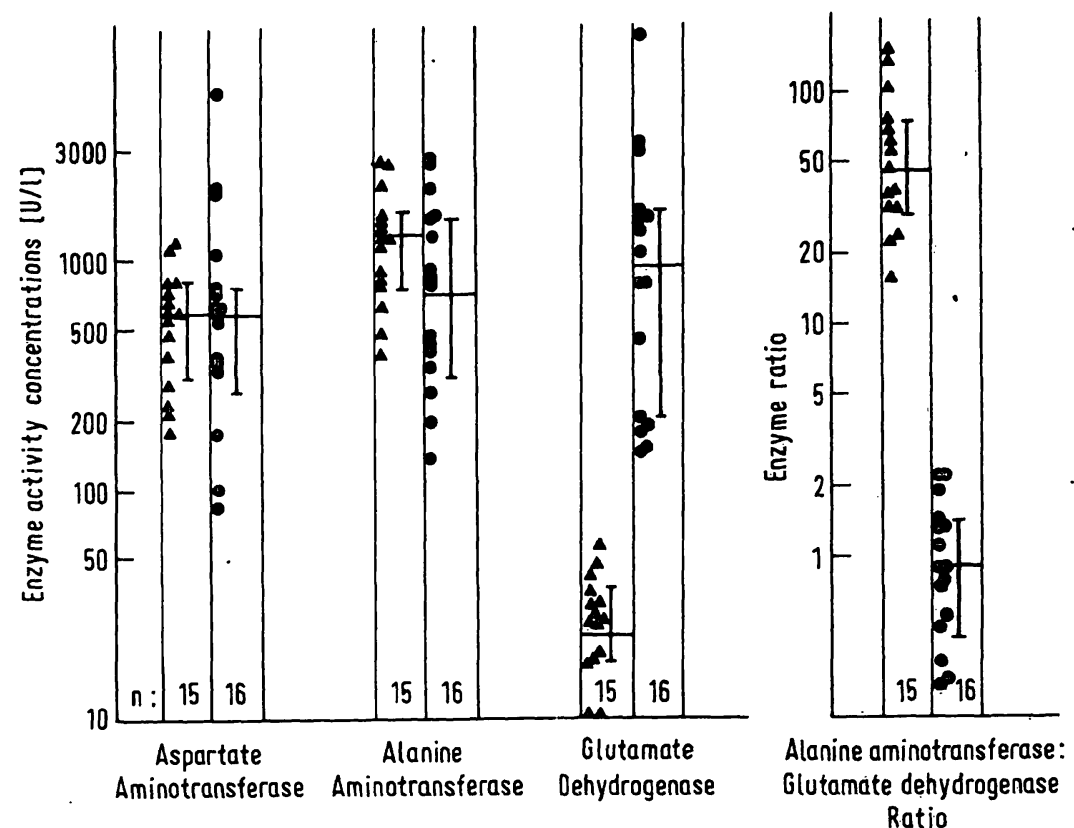

Fig. 3. Comparison of enzyme activity concentrations in serum of cases with acute right heart failure and acute viral hepatitis.

Enzymes were determined in the serum of 16 patients with acute right-sided cardiac failure $(\bullet)$ as listed in table 1 , and 15 cases with acute viral hepatitis during the first week of jaundice ( $\triangle$ ). Each point represents a single determination. Medians \pm 25 percentiles are given, which were determined on probality nets (see methods).

Determination of glutamate dehydrogenase in human liver

\section{Measurements in lyophilized homogenate}

Although numerous methods have been described for the determination of glutamate dehydrogenase in liver extracts (for review see 1. c. (26)), only the method of Lowry (18) appeared suitable for our purposes. This method was adapted to an incubation temperature of $25^{\circ} \mathrm{C}$. The optimum concentrations of substrate, cofactor and activator (fig. 1) were found to be slightly different from earlier studies in more concentrated liver extracts (26) or human serum (19). Thus the optimal concentrations for NADH and ADP were higher, and that for EDTA lower than those of the standard procedure for human serum (19). Under optimal con-

Tab. 2. Glutamate dehydrogenase activitics in microdissected human liver samples from peripheral and central parts of the cords of liver cells.

Liver biopsies were taken during operation, sliced and rapidly frozen in liquid nitrogen as described in the methods. Glutamate dehydrogenase was determined fluorometrically in 10-40 ng dry weight samples microdissected from the central and peripheral parts of liver lobule from freeze dried slices as described in the methods. The biopsies were histologically proven to be normal. None of the patients had pathological aminotranferase or alkaline phosphatase activities in serum. All results are given as medians with the graphically determined 25 percentiles (23) and the number of enzyme determinations in parentheses. Statistical significance of the difference between both groups was determined with the Students $\mathrm{t}$ test and the rank test of Wilcoxon, Mann \& Whitney (23).

\begin{tabular}{|c|c|c|c|c|c|}
\hline Patient & Clinical Diagnosis & $\begin{array}{l}\text { Glutamate Deh] } \\
\text { central }\end{array}$ & $\begin{array}{l}\text { Activity } \\
\text { peripheral }\end{array}$ & $\begin{array}{l}\text { Ratio } \\
\text { central: } \\
\text { peripheral }\end{array}$ & $\mathrm{p}<$ \\
\hline 1. & Cholelithiasis & $405 \begin{array}{l}+75 \\
-80\end{array}(52)$ & $225 \pm 75(52)$ & 1.8 & 0.001 \\
\hline 2. & $\begin{array}{l}\text { Carcinoma of the } \\
\text { stomach }\end{array}$ & $370_{-30}^{+75}(11)$ & $245 \pm 21(10)$ & 1.51 & 0.001 \\
\hline 3. & Cholecystitis & $275 \begin{array}{l}+12 \\
-38\end{array}(15)$ & $163_{-17}^{+33}(14)$ & 1.68 & 0.001 \\
\hline 4. & $\begin{array}{l}\text { Carcinoma of } \\
\text { the antrum }\end{array}$ & $\begin{array}{l}250+33 \\
-25\end{array}$ & $133-45(20)$ & 1.87 & 0.001 \\
\hline Mean & & (95) & (96) & 1.72 & 0.001 \\
\hline
\end{tabular}


ditions activities in lyophilized samples from human liver ranged from 130-450 U/g dry weight, and were thus in the range of earlier reported activities (26).

\section{Measurement in microdissected samples}

Microdissection of defined structures from freeze-dried tissue slices has been shown to be an adequate method for investigation of the distribution of enzymes in various tissues like brain (15), liver (12) and kidney (16). As expected from experiments with kidney, glutamate dehydrogenase activity was not changed during the procedure when compared to the values obtained from lyophilized fresh homogenates and fresh tissue extracts (25).

With this method, glutamate dehydrogenase was determined in samples of 10-40 ng dry weight which were dissected free-hand from peripheral and central parts of the cords of liver lobule. The results obtained from 4 unchanged livers are summarized in table 2. Although there was some variation in glutamate dehydrogenase from one liver to the other, a highly significant difference between peripheral and central parts of human liver was obtained. The mean ratio (central over periphera' activities) was found to be 1.72 , and thus higher than the ratio of 1.32 reported for rat liver (12).

\section{General Discussion}

Interpretation of serum glutamate dehydrogenase activities

The present results demonstrate for the first time an. inhomogeneous distribution of a diagnostically valuable enzyme within the liver lobule in man. Although previous investigations in rat liver $(11,12)$ had shown an enrichment of glutamate dehydrogenase in the central areas of the lobule, this fact has until now not been taken into consideration for the interpretation of serum enzyme patterns. The nearly twofold higher activities found in pericentral liver cells could help to explain the relatively higher serum glutamate dehydrogenase activities found in liver diseases with central necrosis $(4,7-9)$. However, the anatomical difference in enzyme localization can hardly explain the large activity differences found in serum between our patients with acute right-sided cardiac failure and patients with acute viral hepatitis (Fig. 3). Among other factors involved, it has to be considered that both states were compared on the basis of similar alanine aminotransferase activities. This enzyme, however, has been shown to be inversely distributed over the rat liver lobule (12) with a threefold higher activity in the peripheral cells. If this also applies to human liver, there would be an additional factor contributing to the divergent enzyme ratios of our two groups. Besides liver cell heterogeneity, the different degrees of cell necrosis, as proposed by Schmidt \& Schmidt, could also be of importance (4). Moreover, a difference in the biological halflives of alanine aminotransferase ( $47 \pm 10$ hours (24)) and glutamate dehydrogenase ( $18 \pm 1$ hours) has to be considered. As can be seen from figure 2, the alanine aminotransferase: glutamate dehydrogenase ratio increases when enzyme activities return to normal levels. This implies that acutely progressing forms of liver damage would result in relatively higher serum glutamate dehydrogenase activites than would more slowly developing processes.

In spite of these numerous factors which can complicate the interpretation of serum enzyme patterns, the present results may help to explain the relatively high levels of glutamate dehydrogenase observed in cholestatic and metastatic liver diseases $(4,7,9,10)$. Both have been histologically characterized by the preferential occurrence of central liver necrosis (25). The large increase in serum glutamate dehydrogenase in carbon tetrachloride poisoning (27) can also be explained by the pericentral necrosis found under these circumstances. Finally, it should be pointed out that an increase in serum glutamate dehydrogenase is not an obligatory finding in congestive liver disease. Negative results have been reported in cases with chronically elevated central venous pressure, as well as in patients where an acute onset of right heart failure happened to coincide with preformed central fibrosis of the liver $(7,9,28)$. In conclusion, glutamate dehydrogenase determinations in serum, in combination with alanine aminotransferase determinations, seem to be a valuable tool to define not only the degree but also the intralobular distribution of liver cell necrosis.

\section{Physiological considerations}

Uneven distribution of enzymes within the liver lobule has been postulated from the early histochemical work of Gomori (29), and was confirmed in histochemical $(11,30-32)$, electron microscopic $(33,34)$ and biochemical $(35,36)$ studies. Information about the physiological meaning of the described enzyme gradients, however, has been lacking, since metabolic studies with liver cells derived form defined intralobular areas have not been performed. Pette \& Brandau (11) have made the suggestion, based on their histochemical studies, that the higher activities of glutamate dehydrogenase and isocitric dehydrogenase in the central areas of the liver lobule might reflect higher biosynthetic capacities of these cells, but this has not been further investigated. On the other hand, it seems well documented that the uneven distribution of mitochondrial enzymes over the lobule emerges from mitochondria with different 
enzyme patterns rather than from quantitative disproportionality of the mitochondria. As pointed out by Nolikoff (31) and Pette \& Brandau (11), peripheral cells exhibit higher acitvities of succinate dehydrogenase, which is known to be localized in the inner membrane, whereas the matrix enzyme glutamate dehydrogenase is inversely distributed. Beyond its clinical-chemical implications, the present study seems to bear also on the physiological aspects of functional liver cell heterogeneity, which may have developed as an adaptation to the gradients of substrates, oxygen, and hormones built up along the sinusoideal blood flow.

\section{Acknowledgements}

This work was made possible through cooperation of the intensive care units of the 1. Med. Dept. (Head: Prof. Dr. H. Begemann), 2. Med. Dept. (Head: Prof. Dr. E. König), 3. Med. Dept. (Head: Prof. Dr. H. Mehnert), 4. Med. Dept. (Head: Dr. E. Holzer) and Institute of Pathology (Head: Prof. Dr. E. Langer) of the Schwabing City Hospital, and their continuous supporting help is greatfully acknowledged. Human liver samples were made available by Doz. Dr. J. Durst, Surgical University Clinic of Tübingen. Financial support was provided by, the Deutsche Forschungsgemeinschaft (Sonderforschungsbercich 51, Munich and project No. 217/6 Tübingen). The technical assistance of $M$. Schleithoff (serum cnzymes), $A$. Mall (tissue enzymes), and work on the manuscript by $H$. Weissmann (figures) and $A$. Höll (typing) is also greatfully acknowledged.

\section{References}

1. La Duc, J. S., Wroblewski, F. \& Karmen, A. (1954), Science, 120, 497-499.

2. De Ritis, F., Coltori, M. \& Giusti, G. (1957), Clin. Chim. Acta 2, 70-74.

3. Schmidt, E., Schmidt, F. W. \& Wildhirt, E. (1958), Klin. Wochenschr. 36, 280-287.

4. Schmidt, E. \& Schmidt, F. W. (1963), Enzymol. Biol. Clin. 3, 73-79.

5. Schmidt, E. \& Schmidt, F. W. (1962), Klin. Wochenschr. 40, 962-969.

6. Hogeboom, G. H. \& Schneider, W. C. (1953), J. Biol. Chem. 204, 233-238.

7. Schmidt, E. \& Schmidt, F. W. in ,Methoden der enzymatischen Analyse", 3rd edition (1974), 14-30, Vcrlag Chemic, Weinheim.

8. Laudahn, G. (1963), Klin. Wochenschr. 41, 618-619.

9. Weber, H. \& Wegmann, T. (1968), Atlas der klinischen Enzymologie, Thieme, Stuttgart.

10. Filippa, G. (1963), Enzymol. Biol. Clin. 3, 97-128.

11. Pette, D. \& Brandau, H. (1966), Enzymol. Biol. Clin. 6, 79-122.

12. Shank, R. E., Morrison, G., Cheng, C. H., Karl, I. \& Schwartz, R. (1959), J. Histochem. Cy tochem. 7, 237-239.

13. Kleißl, J., Guder, W. G., Gerbitz, K. \& Wieland, O. H., IV. Workshop on experimental liver injury, Frciburg 1974, in press.

14. Kleißl, J., Habicht, A., Guder, W. G. \& Schmidt, U. (1975), this J. 13, 241.

15. Lowry, O. H., Roberts, N. R. \& Chang, M.-L. W. (1956), J. Biol. Chem. 222, 97-107.

16. Schmidt, U. \& Dubach, U. C. (1971), Progr. Histochem. Cytochem. 2, 185-298.

17. Schmidt, U., Schmid, H., Funk, B. \& Dubach, U. C. (1974), Ann. N. Y. Acad. Sci. 242, 489-501.

18. Lowry, O. H., Roberts, N. R. \& Lewis, C. (1956), J. Biol. Chem. 220, 879-892.
19. Empfehlungen der Deutschen Gesellschaft für Klinische Chomie (1972), this j. 14, 182-192.

20. Szasz, G. (1969), Clin. Chem. 15, 124-136.

21. Knedel, M. \& Böttger, R. (1967), Klin. Wochenschr. 45, 325-327.

22. Schlcbusch, H., Rick, W., Lang, H. \& Knedel, M. (1974), Deut. Med. Wochenschr. 99, 765-766.

23. Sachs, L. (1972), "Statistische Auswertungsmethoden", 3rd ed., Springcr, Heidelberg-Berlin-New York.

24. Bär, V. \& Ohlendorf, S. (1970), Klin..Wochenschr. 48, 776-780.

25. Popper, H. \& Schaffner, F. (1957), ,, Liver: Structure and Function", McGraw-Hill, London.

26. Schmidt, E. (1974), in „Methoden der enzymatischen Analyse", 3rd ed. 689-696, Verlag Chemie, Weinheim

27. Schmidt, E. \& Schmidt, F. W. (1973), Scand. J. Gastroent. 8, Suppl. 19, 13-35.

28. Rettenbacher-Däubner, H., Rieder, H. \& Sburny, I. (1967), Acta Hepato-Splen. 14, 209-221.

29. Gomori, G. (1941), J. Cell Comp. Physiol. 17, 71-83

30. Schumacher, H. H. (1957), Science 125, 501-5:03.

31. Novikoff, A. B. (1959), J. Histochem. Cytochem. 7, 240244.

32. Noltc, J. \& Pctte, D. (1971), in „Recent Advances in Quantitative Histo- and Cytochemistry", 54-60, Huber, Bern-Stuttgart-Vienna.

33. Loud, A. V. (1968), J. Cell Biol. 37, 27-46.

34. Reith, A., Schüler, B. \& Vogell, W. (1968), Z. Zellforsch. 89, 225-240.

35. Werner, S. \& Neupert, W. (1973), Eur. J. Biochem. 25, 379-396.

36. Weiss, G., Lamartinière, C. A., Müller-Ohly, B. \& Seubert, W. (1974), Eur. J. Biochem. 43. 391-403.

Priv. Doz. Dr. W. G. Guder

Cand. med. J. Kleißl

Prof. Dr. O. H. Wieland

Klinisch-chemisches Institut

Städt. Krankenhaus München-Schwabing

D-8000 München 40

Kölner Platz 1

Dr. A. Habicht

Doz. Dr. U. Schmidt

Cytobiologisches Laboratorium

des Pathologischen Instituts

der Universität

D-7400 Tübingen

Liebermeisterstr. 8 